This is a draft version. For the published article follow the link to

Rethinking History 20:2 (2016)

or this one to

$\underline{50 \text { free eprints }}$

\title{
We are history: the outlines of a quasi-substantive philosophy of history
}

\author{
Zoltán Boldizsár Simon \\ Bielefeld Graduate School in History and Sociology, University of Bielefeld, Germany
}

\begin{abstract}
In times of a felt need to justify the value of the humanities, the need to revisit and reestablish the public relevance of the discipline of history cannot come as a surprise. On the following pages I will argue that this need is unappeasable by scholarly proposals. The much desired revitalization of historical writing lies instead in reconciling ourselves with the dual meaning of the word history, in exploring the necessary interconnection between history understood as the course of events and as historical writing. Despite the general tendency of the last decades to forbid philosophizing about history in the former sense (at least in departments of history and philosophy), I think that to a certain extent we already do so without succumbing to substantive thought. We already have the sprouts of a speculative although only quasi-substantive philosophy of history that nevertheless takes seriously the postwar criticism of the substantive enterprise. In this essay I will first try to outline this quasi-substantive philosophy of history that attests to the historical sensibility of our times; and second, I will try to outline its consequences regarding history as historical writing. Finally, in place of a conclusion I will suggest that historical writing is not as much a contribution to public agendas as it is the very arena in which public life is at stake.
\end{abstract}

\section{Keywords}

identity; knowledge; presence; quasi-substantive philosophy of history; disrupted singular; the public relevance of history 


\section{The logic of proposals and the task of understanding}

For as long as I can remember, history (understood as historical writing) has been in crisis. True enough, it was said to be in crisis even before I was born. It was said to be in crisis throughout the entire postwar period, and generally speaking there has been plenty of crisis-talk surrounding history since its institutionalization. What this series of felt crises betrays is, I think, a constant urge for change that, even more generally speaking, might characterize the entire modern period. But regardless of whether these crises are reasonably felt, regardless of whether the changes they evoke are only overdecorated bagatelles as they often prove to be, one thing looks certain: the constant urge for change these crises evince, craves satisfaction.

Within academia, a customary route to satisfaction seems to be to come up with proposals that 'challenge' received wisdom by putting forth 'bold' and 'provocative' ideas in order to achieve 'radical' conceptual shifts. I will call this customary route the logic of proposals, which informs both our academic debates in general and our debates regarding history in particular. As for debates about history, the current flow of proposals reflects a present crisis of history, revolving around the desire to turn history into a valuable contribution to public life. ${ }^{1}$ To be clear, at issue is not the contribution of the past to present-day cultural, social, environmental and political concerns; at issue is the contribution of a particular way of making sense of the world, of a certain way of relating to the past, which can be regarded as a specific characteristic of professional history exercised by historians. Accordingly, the question is not merely one of how historical writing can be of public relevance, but how history qua history and historians qua historians, as practitioners of a specific way of making sense of the world, could contribute to public life and public agendas - if such a thing is possible at all.

In the most general terms, it is the relevance of historical sensibility for our contemporary life and the question of the form this historical sensibility is supposed to take today that is at stake in the abundance of the proposed conceptual revisions we have witnessed lately. This is the main concern of Hayden White's recent embrace of the notion of the practical past (White 2014), of efforts to reconceptualize notions of time and temporality, either somewhat sharply (Ermarth 2011) or more modestly (Bevernage and Lorenz 2012), of calls to re-examine our 
relations to the past in the broadest terms (Paul 2015), or of The History Manifesto, coauthored by historians Jo Guldi and David Armitage (2014), a short book offering a lengthy scholarly proposal that is manifesto-like only in its title. The curious thing about all these proposals is that the urge for the deep conceptual change they attest to seems unappeasable by them. The reason for this is that the logic of proposals is a rather self-preserving practice in which any proposal is just an invitation for another to 'go beyond' it tomorrow. The result is a situation best described by the Rolling Stones hit (I Can't Get No) Satisfaction, where the permanent desire for satisfaction is accompanied by knowledge of the impossibility of getting it (as is conceded in the parentheses that, tellingly, precede the main theme). This impossibility, I believe, lies at the very heart of the logic of proposals. In their efforts to trump each other, proposals defy the very possibility of fulfilling their objective, namely, the achievement of a 'radical' conceptual shift concerning not only yesterday's proposals but the subject of all proposals: a change that cannot be superseded the next day.

Such desired changes are changes in conditions of possibility, which, by definition, are not well-formulated and deliberate proposals but hidden dispositions that make deliberate proposals possible and establish their confines. They can be unveiled by deliberate acts of academic critique (a practice that proposals build upon), but cannot be replaced by these very same acts. Hence most of the proposals concerning the reconceptualization of history (or of anything else practically) are brilliant in unveiling and analyzing that which they wish to supersede or exchange, but helpless and clumsy in offering new configurations - simply because, to repeat my point, a spectacular conceptual shift is not something that can be offered as a proposal.

If proposals are nevertheless able to unveil what they consider to be wrong conceptualizations, it is precisely because those conceptualizations are not regarded as being theirs anymore. But if something is properly left behind, as they all seem to think, if something does not apply anymore, then it simply makes no sense to suppose that it left a vacuum of thought and was not already exchanged for something else, even if this new something still remains to be properly articulated. Therefore, in an intellectual atmosphere with a shared sense that certain conceptual dispositions no longer apply, the task is not to devise something that could fill a supposed vacuum of thought, but to look around within our own cultural practices and come to terms with what is already going on instead of what no longer applies. The sensible thing to do in this situation is, I think, to get out of the circuit of proposals, to halt, to stop for a moment in the middle of the rush, to look around 
and attempt to understand something that we, at least to some extent, already have at our disposal.

To put it differently, I think that the challenge we face today in the theory and philosophy of history lies in making the implicit explicit. And it is precisely this task of understanding and of trying to articulate something already implicit that I wish to take on with regards to the question of how history qua history and historians qua historians shape public life today. The question itself, insofar as it demands universality and insofar as it concerns the conditions under which history as historical writing might be able to live up to its own apparent expectations, is a rather theoretical one. It means that no answer to this question will enable answering the question about how, in what particular way, historians could make history instrumental for public life in the first decades of the twenty-first century. What answering the question about the conditions brings to light instead is the mode in which history inevitably is of public relevance today, regardless of particular proposals concerning the how. Practically speaking, what such an answer could suggest is, at best, a way to distinguish between viable and less viable proposals: between proposals that work with new conceptualizations and those that eventually fall prey to that which they wish to supersede.

As for sketching the mode in which history qua history inevitably is of public relevance today, my point of departure will be the dual meaning of the word history, understood both as the course of events and as historical writing. The reason for this is that professional historical writing and the philosophy of history that offered an overall interpretation of the course of human events accompanied by an overall meaning to a postulated movement of history were joint products of a time when the concept of history as such became thinkable in the period that Koselleck (2004) calls Sattelzeit. ${ }^{2}$ Due to their interdependence (of which I will talk more about later), they exhibit a shared set of conceptual tools. Yet the theoretical work of the last decades has revolved around the agenda that we should drop any philosophical and theoretical talk of history in the former sense and reserve the word exclusively for theorizing historical writing. ${ }^{3}$

Now, my basic contention runs counter to this and goes as follows: examining the sense in which it is possible to talk about the movement of history today, that is, tracking a conceptual shift concerning the enterprise of philosophy of history as a philosophy of the course of events, reveals a great deal about the outlines of a conceptual shift concerning history as historical writing. In other words, the 
reconceptualization of the latter does not come in the shape of proposals but as a necessary entailment of the way we already think differently about the movement of history, about how change takes place in human affairs. Traces that we already do so - and that it is possible again to talk about the movement of history in the first place - are, I think, clearly detectable in the work of philosophers like Alain Badiou or Jean-Luc Nancy. It is equally apparent in the more specific aim of Eelco Runia to devise an up-to-date philosophy of history, and, however unintentionally, it is implied in Frank Ankersmit's recent work on historical experience. Separately, none of these efforts break away (and some of them do not even try to break away) from the conceptual framework of the philosophies of history of the Enlightenment and German Idealism. However, they all indicate aspects in which they do, and seeing those aspects together might result in a quasi-substantive philosophy of history that conceptualizes the movement of history in a new framework (a situation that I outlined in more detail in Simon 2015b).

That being said, on the coming pages I will run the following argument to answer the question of how history qua history inevitably shapes public life. As a first step, I will begin by sketching the notion of history that a quasi-substantive philosophy of history might offer today. In doing so, I will outline the sense in which this quasi-substantive view of history as the course of events differs from the developmental view of classical philosophies of history and attempt to explore the temporal configuration that underlies this new movement of history. The notion of history that emerges from these investigations is what I will call history as a disrupted singular. What this means is that whereas the notion of history harboured by classical philosophies of history accounted for change as the development of a single ontological subject - humankind, reason or freedom - within a flow of time, the concept of history that I think we already have at our disposal accounts for change by considering disruptions in time that bring about ever new ontological subjects new human communities - in terms of identity shifts.

In the next step of the argument I will try to unpack the conceptual consequences that the notion history as a disrupted singular has for the questions of how we relate to the past and how we think about the task of historical writing. What I will try to show is that historical writing - by providing essentially contested knowledge of the past - is the best tool we have for negatively indicating the contours of the future community that is presently taking place. Although we cannot have knowledge about what we are to be (about what community is coming to existence), historical writing 
functions as the indicator of what we will not be by revealing what we no longer can be. Eventually, all this will enable me to argue that historical writing is not as much a contribution to public agendas as the very arena in which public life is at stake. It is the very arena because history as the course of events is our public endeavour per se, within which historical writing acquires the aforementioned function and which makes historical writing possible in the first place.

\section{The movement of history}

Thinking about history as the course of events begins not in the past but in the idea that the past should be seen together with the present and the future. The substantive philosophies of history of the Enlightenment and German Idealism did exactly this when they postulated an ultimate meaning of an entire historical process in the future, which retrospectively explains past events as directed toward a future fulfilment. Later, in the postwar period, it was exactly this operation that became the primary target of criticism: the supposed knowledge of the future from which knowledge of the past could be derived was the main ground for ridiculing and for refuting the entire substantive enterprise as illegitimate (cf. Danto 1985, 13).

This specific constellation that could not withstand postwar criticism is, of course, not the one that could or should be reinstated. The unity of past, present and future in the shape of a continuous temporal plane as a matter of knowledge in its entirety, the flow of time as the background against which the unfolding of a single ontological subject as the substance of the historical process - humanity, freedom or reason - could take place within and as the whole of history, the view that Maurice Mandelbaum (1971) called the developmental view, is not a temporal configuration that could underlie the movement of history today. ${ }^{4}$ The philosophy of history of our times, if it intends to take critiques seriously, cannot be other than quasi-substantive. ${ }^{5} \mathrm{It}$ can still be a philosophy of history inasmuch as it postulates a movement and a mechanism (or a pattern) to account for change in the course of events just like substantive philosophies of history did; but it can be only quasi-substantive inasmuch as due to an abandonment of temporal unity, it lacks a proper substance as the development of a single unfolding subject as history.

Be that as it may, for historians and philosophers alike, the seduction of developmental and substantive thinking is still hard to withstand. The authors of The History Manifesto, for instance, still assume temporal unity in arguing for 'thinking 
about the past in order to see the future' (Guldi and Armitage 2014, 4), while Alain Badiou somewhat habitually associates what he sees as 'the rebirth of History' with the 'rebirth of the Idea' - which, for him, is still the 'idea of Communism' (Badiou 2012 , 6). Badiou's insistence on something like the Idea that cannot but retain the function of a substance in a historical process is all the more unfortunate because it overshadows Badiou's more important and less essentialist thoughts on a future other than the fulfilment of something that is already and always was there, unfulfilled. In his more important and less essentialist moments Badiou rather talks about a future we have to think today exactly in order to avoid substantive thinking, namely, the future coming-to-existence of an ontological subject that had no prior existence. This, I believe, is what Badiou sees in recent riots as the birth of 'people, who are present in the world but absent from its meaning and decisions about its future, the inexistent of the world' (Badiou 2012, 56). As potential subjects of a historical process, the previously 'inexistent' and the Idea are, I think, irreconcilable. They are different in kind, just as the way they respectively come about. The Idea that is yet to be fulfilled as an ultimate meaning comes about in a development of becoming, while the previously 'inexistent' is just being born without a previous stage out of which it could develop in order to eventually reach a point of becoming.

To avoid Badiou's mistake of taking recourse in a substance in the course of events, the first task of a quasi-substantive philosophy for our times is to think a future as the 'coming' of a new subject that does not 'become,' a subject that is about to be born without originating in and unfolding from the past. And this precisely is the leitmotif of Jean-Luc Nancy's idea of a community in its happening, the prospect of the announcement of a future 'we,' which, I think, is what a quasi-substantive philosophy of history has to take as its point of departure. Only as its point of departure, however, because even if Nancy (1993) does equate the coming-toexistence or coming-to-presence of a future 'we' with history in order to escape substantive thinking, his notion of history is anything but historical by virtue of lacking the dimension of change in a crucial respect. As to the efforts to escape substantive thought, Nancy tries to think the 'taking place' of a subject in its very act of happening. Thinking the subject of a human community it in its very act of happening means that 'rather than an unfolding, rather than a process or procession, the happening or the coming - or, more to the point, "to happen," "to come," "to take place" - would be a nonsubstantive verb and one that is nonsubstantifiable' (Nancy 2000, 162). That such 'coming' or 'taking place' of a subject entails the 
abandonment of the entire idea of development is especially clear when Nancy assures readers that the subject in question 'does not come from the homogeneity of a temporal process or from the homogeneous production of this process out of an origin,' and 'that the origin is not and was never present' (Nancy 1993, 162).

As for the lack of the dimension of change in a very crucial respect, that is coded into what I see as the perpetual stream of Nancy's notion of 'coming' and 'taking place.' Unlike a process of becoming that implies a motion directed towards an altered condition, the motion implied by a perpetual 'coming' keeps its subject in the very same condition. Whereas the 'becoming' of the substance in substantive philosophies of history entailed a concept of change as stages of development leading to an ultimate fulfilment, Nancy's 'coming' does not lead to any ultimate altered condition nor to changes along the way, simply because there is no 'way' leading anywhere. Insofar as the future community (as the subject of history) is always in its happening, insofar as it is 'coming' without ever 'becoming,' it has forever to be unrealizable, forever to remain an unannounced 'we,' sentenced to infinite deferral. Thus, it seems that excluding the dimension of change is the price Nancy has to pay for equating history with the future, with a coming 'we,' which nevertheless enables him to cut ties with the past, to imagine a future ontological subject that has no prior existence and thus no origin from which it could unfold. ${ }^{6}$

Yet no philosophy of history (as the course of events) is possible without accounting for change, which, in turn, necessitates not only the future, but also the present and the past. Therefore, the task is to find a way to reconcile the idea of change and the idea of a perpetual coming-to-presence or coming-to-existence of a new ontological subject. Change, however, cannot have the same characteristics it had in substantive philosophies of history: it cannot mean stages of a development of a subject that nevertheless retains its self-identity. In the case of a future coming-topresence or coming-to existence of a new ontological subject, change has to mean a change in that very identity, that is, a change of the subject of a postulated historical process. Change here has to mean the perpetual alteration of ever new ontological subjects, each of them being a coming 'we' without an origin, without a previous state from which they could develop. Just because the coming-to-existence of a new ontological subject has to be of no origin in order to avoid substantive thought, it does not have to mean that it cannot be superseded by another one, and then another one, again and again. 
Now, having a look at current philosophies of history, what brings together the recent efforts of Runia (2014) and Ankersmit (2005) is precisely their shared interest in the most momentous changes in human affairs: changes that are deeply traumatic; changes that are the result of events they both label 'sublime;' changes that destroy 'the stories we live by,' (Runia 2014, 124) and changes through which 'one has become what one is no longer' (Ankersmit 2005, 333). These disruptive changes - of which the French Revolution is the paradigmatic example for both of them - appear as discontinuities in identity constitution, as dissociations from the past. If the stories that a certain 'we' lives by are destroyed in these disruptive changes, then what is born in the midst of such traumatic events is a new 'we' that is discontinuous with and dissociated from the 'we' whose stories have been destroyed. Or, to put it differently, in such momentous changes a new subject is being born, from whose viewpoint the destroyed stories must have belonged to a 'them' which, as a 'them,' once was also born in the midst of a momentous change and as a previous 'we' it also had to have its 'them' to dissociate from, a 'them' that once was also a 'we,' and so on - all this making up a movement or mechanism based on discontinuous change.

Within such a movement (a movement that I outline in more detail in Simon 2015b) the identity of a certain 'we' cannot be established by invoking its past simply because that is only its past, not its history. Runia, very much in line with Nancy, associates the latter with the future in claiming that 'our history really is before us' (Runia 2014, 8). Aside from this remark, however, Runia does not have much to say about the future. His more interesting claims concern the past - particularly the claim that it is due to the aforementioned momentous changes that the past can be known, that it is due to them that 'we come to see what is lost forever: what we are no longer' (Runia 2014, 16). As a result, with this claim, the most important aspect of introducing the dimension of change in the shape of ruptures becomes apparent. It is the recognition that the past and the future are subjects of activities of a different kind, that they satisfy different kinds of desires. In a quasi-substantive philosophy of history the past is a matter of knowledge and the future is a matter of existence, while the movement of bistory is the perpetual transformation of the matters of existence into the matters of knowledge.

To sum up, there are two points to keep in mind when thinking about history as the course of events today. First, in order to be only quasi-substantive, the future in which a quasi-substantive philosophy of history begins must be the coming-toexistence of a new ontological subject. Second, in order to qualify as a philosophy of 
history that explains change, a quasi-substantive philosophy of history has to posit a series of comings-to-existence of new-born subjects, separated from each other by disruptive, momentous events, instead of speaking of one single subject that could play the role of a substance in a historical process. Neither Nancy's philosophy nor recent philosophies of history interested in change fulfil both conditions. But the ideas they entertain separately - that of 'coming' and that of momentous change can nevertheless be put to work to confine and inform each other. ${ }^{7}$ The concept of history that emerges from this operation is history as a disrupted singular, a concept that I would like to introduce in the following section in order both to review and elaborate on what I have said so far.

\section{History as a disrupted singular}

A philosophy of history that wishes to avoid substantive thought can employ the word history in three distinct senses: in a prospective sense, in a retrospective one, and, most importantly, in a sense that encompasses both as a movement. The prospective sense is the one that had a prominent role in the previous section: it is history as equated with the future, our history ahead of us - our 'coming' community. It means neither the course of events concerning things done nor historical writing, but things about to be done. It concerns a future existence of which we cannot have knowledge, for it is not a matter of epistemology but of ontology, if anything. Finally, as a 'coming' without ever 'becoming,' it indicates a clear break with the developmental view that characterized substantive philosophies of history as well as historical writing as it became institutionalized in the early nineteenth century.

The retrospective is the familiar sense of historical writing. The different understanding of the prospective, however, requires a modification to the retrospective sense too, which concerns the function of historical writing in identity constitution. For if the future is not the final stage of a 'becoming,' then our retrospective stance cannot be based on the view that understanding something means inquiring into its past (from which it unfolds and proceeds to its future state). In the retrospective stance of a quasi-substantive philosophy of history there is nothing like a different past state of the otherwise same present identity; there is only another identity. One might nevertheless object by noting that there is nothing new here, given that the past has been the 'other' ever since the institutionalization of the 
discipline. And the objection would be partly right, but only partly. It is true that even in the developmental view the past was the 'other.' Yet that 'other' was always an earlier version of a present 'we,' much like in the Terminator movies, where the T800 (the living tissue over a metal endoskeleton) is an earlier version of the 'advanced prototype' T-1000 (the mimetic poly-alloy), as the T-800 actually refers to its successor. In other words, the past 'other' in the developmental view is who the present 'we,' notwithstanding and despite its altered past states, always was. In distinction, in a quasi-substantive philosophy of history the 'other' is who the coming 'we' never was.

To rephrase things more emphatically, the 'other' is another ontological subject, meaning that historical writing cannot answer 'our' identity questions by turning to the past anymore. It cannot answer the question of who 'we' are, because 'who we are' now means 'who we are about to be' prospectively, in the happening of 'our' history, which, by definition, cannot be known. Thus, in a quasi-substantive philosophy of history, the retrospective stance associated with historical writing shifts from an approach that positively connects to an approach that disrupts. Similarly to negative (apophatic) theology, according to which God cannot be described in positive terms, history in this sense can answer our identity questions only by negation. Nevertheless, the negative answers inform us about who we are not, and by virtue of their exclusion, they can still be indicative of what the coming 'we' is about to be. This negative definition gains significance in the light of the irony of the story, namely, that if prospectively 'we' never become, and if retrospectively we can know only what 'we' are not, then we can never know who 'we' actually are. What we can know, what historical writing can tell us, is who we no longer are and hence what the coming 'we' cannot be.

Finally, and most importantly, it is necessary to consider these two senses of history as they meet at a present point of disruption, from which the former sense of history applies prospectively and the latter retrospectively. Seen together, the past, the present and the future make up what I would call history as a dismpted singular. On the long run, consisting several disruptive moments and transformations, this is the mechanism of a perpetual transformation of unknowable 'coming' histories into dissociated, apophatic pasts. From points of disruption, the retrospective and the prospective stances satisfy two different kinds of desires. Yet, as odd as it may sound, points of disruption also function as points of connection, given that it is seen from 
these points that both sides of history as a disrupted singular play the same endless game: identity formation.

This history as a disrupted singular departs both from the late-eighteenthcentury invention of history as a collective singular according to Koselleck (2004, 3337). There is a dual departure because Koselleck's analytical framework is based on the very same temporal configuration as its subject of analysis, the concept of history as a collective singular. To sketch the framework very briefly, in its core there are two anthropological constants, the categories of a 'space of experience' and a 'horizon of expectation,' whose inner relations structure the experience of time. The kind of change that can happen in the Koselleckian framework is a change in the internal relation of these categories, like the change Koselleck associates with Neureit, when expectations moved away from previous experiences in an accelerating fashion, giving way to the temporal configuration in which history as a collective singular became thinkable. But however far expectations may move from experiences, Koselleck's categories work on the premise of continuous succession, as they themselves are products of the notion of history whose birth and characteristics Koselleck investigates. However thin that continuity between experiences and expectations might become in Nenzeit, both experiences and expectations concern one single ontological subject whose past and future is at stake in a present moment. The one single subject, whose association with both the past and the future takes place in a present moment, necessarily creates temporal unity and continuity.

Contrary to this, the temporal configuration that underlies the concept of history as a disrupted singular is based on discontinuity and disruption. The past cannot be a space of experience simply because it no longer concerns the experiences of the same ontological subject that comes-to-existence on the prospective side, but the experiences of a 'them' that is anything but the 'we' in its formation. In a similar vein, the future cannot form a horizon of expectation as it simply does not concern the prospective projection of a past subject, but the birth of another subject that did not exist previously. To put this in a somewhat thesis-like way: the temporal configuration that underlies the notion of history as a disrupted singular is not a relation between a space of experience and a horizon of expectation within a flow of time, but a space of dissociated knowledge and a horizon of existence against the background of a disruption of time. ${ }^{8}$ 


\section{Our apophatic past}

The movement of history as a disrupted singular sketched above sets the conditions under which history as historical writing operates as knowledge about our past. Insofar as historical writing is about past events and occurrences, the role attributed to the retrospective stance in the overall picture is instructive of the function and role of historical writing. To run a brief review, in the previous section it became clear that the past can only be a negative contribution to a coming identity; its instrumentality lies in our attempts at defining who a coming 'we' is about to be by indicating what the 'we' in question can no longer be. According to the analogy to apophatic theology also mentioned in the previous section, I would like to call this past our apophatic past. This may sound somewhat outlandish or clumsy, but is at least indicative of the function of our backward stance in identity constitution. Besides, sounding outlandish may not be a bad thing after all, taking into consideration what the phrase stands for.

But what exactly does the phrase stand for? What exactly do I mean by an apophatic past? To begin with, I mean a dissociated past. Yet, I mean much more than a simple present dissociation from a past condition or state of affairs. The apophatic past can only be understood in relation to the future, which is not the result but the source of a backward stance. This is so because it can only be a postulated future viewpoint, the viewpoint that one has in a coming community, from where the past looks apophatic, from where the past appears as a matter of dissociated knowledge about what the coming community is not and what it cannot be. The importance of this operation cannot be overstated. For if the coming 'we' cannot know its identity, it has no other choice than to attempt a self-definition - a self-definition which can never fully succeed - by negation, by making use of the only usable thing at hand in that matter, the apophatic past, and hence by the practice that studies and creates (creates by studying/studies by creating) such a past: historical writing.

The first thing I have to concede about this notion of an apophatic past is that it seems to be at odds with the two most fashionable recent proposals about how we should relate to the past: the practical past as advocated recently by Hayden White, and the notion of a present past. To start with the former, when White (2014) turns to Michael Oakeshott's distinction between the practical and the historical past (introduced in Experience and Its Modes in 1933), what he is concerned with is not the conceptual redefinition of the distinction, but a re-evaluation of its respective sides. 
On Oakeshott's account, the distinction looks like this: the historical past is a 'dead past' and its distinctness lies in 'its very disparity from what is contemporary' (Oakeshott 1966, 106), while the practical past comes to the fore 'wherever the significance of the past lies in the fact that it has been influential in deciding the present and future fortunes of man, wherever the present is sought in the past' (Oakeshott 1966, 103). Whereas the historical past describes the relationship of professional historians to the past, the practical past describes our everyday attitude towards it. As it stands, White seems to be perfectly content with this conceptual framing. But unlike Oakeshott, who passed a positive judgment on the historical past in order to grant the autonomy of historical knowledge by showing that it is a distinct mode of experience in its own right, White - having very different objectives - calls for an embracement of the practical past. ${ }^{9}$

His embracement, however, suffers from the same deficiency that The History Manifesto does: the advice to tell stories about the past that might guide our future actions exhibits the notion of temporality entailed in the developmental view. ${ }^{10}$ As I have dealt with this issue more extensively on another occasion (Simon 2015a), I would here like to mention only the core of the problem with the concept of history that White has lately advocated. It is that the notion of the practical past - and, actually, the entire distinction between the historical and the practical past - makes sense only on the premise of a historical process within which an unfolding subject retains its self-identity in the midst of all changes in appearance. Accordingly, it does not come as a surprise that 'continuity in change' is a recurring theme in the argument of White (2014, 68; 100-103), describing the temporal structure within which the practical past makes sense. White's insistence on this temporality and on the idea that 'we need the illusion of substance' (White 2014, 103) insofar as we want to act upon stories based on the practical past, clearly exhibits the very same temporal order upon which classical philosophies of history were erected. What is more, White $(2014,14-16)$ explicitly associates these philosophies of history with the pursuit of the practical past (White 2014, 14-16), which, needless to say, is indeed in sharp contradiction with a quasi-substantive philosophy of history, with the notion of history as a disrupted singular and with a past that is apophatic.

As for the notion of the present past, the intellectual environment in which White raised the issue of the practical past was already sparkling, thanks to the freshly emerging notion of 'presence.' It seems to entail a timelier - or, as Ghosh and Kleinberg (2013) indicate, maybe even the timeliest - offer to account for our 
relations to the past. Besides the literary and cultural theorist Hans Ulrich Gumbrecht (2004), the two names that pop up most often in discussions of the notion are the ones whose ideas were already instructive in the previous sections: Runia (2014, 49-83) and Nancy (1993). There is, however, a crucial difference that usually goes unmentioned. It is only Runia for whom presence means the presence of the past and for whom the past (that is, by definition, a non-present) can break its way into the present. In contrast to this, presence for Nancy always concerns the future as a coming-to-presence; instead of talking about something (the past) breaking into the present, Nancy's ideas rather leave the present void of presence. Due to this all-important difference - on which I will elaborate later - it is not on Nancy's but on Runia's premise that the notion of presence pervaded the postmillennial theory and philosophy of history.

In Runia's theory the past seems to be able to make its way into the present on two levels. The first level concerns historical writing, regarding which Runia endows the linguistic trope of metonymy with the capability to transfer presence and claims that 'historical reality travels with historiography not as a paying passenger, but as a stowaway' (Runia 2014, 81). The second level concerns existence, and Runia's claim is that 'the past may have a presence that is so powerful that it can use $u s$, humans, as its material (Runia 2014, 88). His primary example for this is the case of the Dutch historians of the Srebrenica commission, who, according to Runia (2014, 17-48), reproduced or 'acted out' the defence and argumentation of Dutch soldiers whose acts (the killing of 8,000 Bosnians under their 'guidance') they were supposed to be studying. Discussions of these two levels blend in Runia's work, often resulting in unnecessary confusion about the notion of 'presence.' Thus, for the sake of clarity it seems important to note that it is one thing to state that texts can, due to present human intervention, be crafted to convey presence (what literary theory calls experientiality), ${ }^{11}$ and another to claim that a past existence invades and takes over the present without present human intervention, as Runia appears to think in the passage quoted above.

Even though I find this idea of human passivity considerably troublesome, I have to admit that it is nevertheless on this second, ontological level that the notion of the present past might be useful for efforts that seek to reconceptualize time and temporality in a way different from the developmental view. That being the case, the question to ask is: Can this notion be linked in any way to history as a disrupted singular? At first glance, the answer seems to be a rather obvious 'No, it cannot.' 
Indeed, how could anyone imagine that the past that breaks into and takes over the present, a past with which the present necessarily becomes associated, has anything to do with the apophatic past, dissociated from the present?

The answer I wish to suggest is that the notion of 'presence' in historical theory and thus the idea of the present past can be regarded as the counterpart of what I call the apophatic past. Not in the sense of their being each other's evil twins, and not as if one could be favoured and set up as a standard to follow against the other. Moreover, neither are they counterparts in the sense that one of them could be recommended for historical practice at the expense of the other, nor complements in the sense that one could apply to historical practice while the other could describe a relation to the past beyond the concerns of professional historical writing. This constellation may perfectly describe the relationship between the historical past and the practical past in Oakeshott's and White's thinking. But in the case of the concept of history as a disrupted singular, the link between the present and our apophatic past concerns a more primordial and elementary relation in which they are counterparts insofar as they are existentially bound together.

This existential binding stems from the characteristics of the prospective side of history as a disrupted singular. ${ }^{12}$ Only together do the present past and our apophatic past attest to the fact that the coming 'we' is never an achievement but only the prospect of a 'we,' of the history we have ahead of us. Because the 'we' in its happening and coming-to-presence is never realized, our apophatic past also cannot be fully 'realized' as the past as such (the entirety of the past). If the future comingto-presence and coming-to-existence provides the basis for retrospective dissociation, and if this future coming-to-existence is never achieved, full dissociation from the past can never take place. Consequently, there has to be another past that is not apophatic and not dissociated. And insofar as the backward stance of historical writing is a backward stance, then its territory is the past as such, and this territory cannot be merely our apophatic past about which we can have dissociated knowledge, but also a past that breaks through, a present past.

Thus whenever we say 'past,' and whenever we say that historical writing is about the past, this past is an inseparable blend of the present and the apophatic past, a blend of our associative and dissociative measures. The past that historical writing is about, is neither purely present and associated, nor purely dissociated and apophatic, that is, neither purely ours, nor purely not ours. As odd and counterintuitive as it may sound, because the point of orientation is always the coming 'we,' in a 
quasi-substantive philosophy of history the past is ours by virtue of our never having had it, and the past is not ours by virtue of our still having it.

Whenever and in whatever respect we still have the past in the present whenever and in whatever respect the past has 'presence' in the present - the past fills the present with existence. It would be hard, or even impossible, to imagine that the present is devoid of existence, and if the coming 'we' is, by definition, nonpresence, then the present has to be filled with existence provided by the past. And in this sense the past is even more extremely present than Runia thinks, and the 'we' in its happening is even more extremely only coming-to-presence (that is, even more extremely non-presence at every present moment) as Nancy thinks. Nevertheless, the more distinct and the more extreme they look, the more the present and the apophatic past demand and complement each other. To encapsulate the essence of all this, I would like to offer the following thesis: The notion of the past as such necessitates the interdependence and intertwinement of a past that is ours by virtue of being dissociated and nonpresent (the apophatic past) and a past that is not ours by virtue of being associated and made present (the present past).

\section{Essentially contested historical knowledge}

That being said, there is a question that introduces further complexity: if the retrospective side of history as a disrupted singular is historical writing as knowledge about our apophatic past, and if the past as such is not only apophatic but also present (that is, not entirely dissociated and therefore not entirely a matter of knowledge), then how could historical writing live up to its implied task? Can historical writing be knowledge about the past, notwithstanding the extent to which the past is not dissociated but present?

The answer, I think, is a rather rewarding one. To unpack it, I would like to contrast once again the distinction between the practical and the historical past with the distinction between the apophatic and the present past. As to the former, the practical past/historical past divide implies a not-so-hidden distinction between matters of existence and ethics on the 'practical' side and matters of knowledge on the 'historical' (which is also the bulk of the criticism White receives in Lorenz 2014, 45-46). The historical past, the dead past, may be the equivalent of the apophatic past in my apophatic past/present past division in the most crucial sense that both are defined by dissociation. The same equivalence may concern the practical past and 
the present past insofar as both are defined by an associative relation between past and present. Yet the historical past in White's and Oakeshott's account is not only a dissociated but also a disinterested and detached past, studied for its own sake. It is precisely on the basis of this attributed disinterest and detachment that the notion of the historical past is deprived of ethical and existential concerns and consequently becomes a matter of historical knowledge. Correspondingly, it is due to the attributed interest and engagement on the side of the practical past that ethics takes over knowledge.

Now, contrary to this, the apophatic past/present past distinction is anything but a clear division between disinterest and detachment about the past on the one side and interest and continuing present engagement on the other. The apophatic past is just as much a presently engaged past as its counterpart, the present past. What distinguishes and also makes them counterparts is that the apophatic past engages by negation, while the present past engages by affirmation. This dual engagement, and, more importantly, the intertwinement and contemporaneity of the apophatic and the present past as the very same past, collapses matters of knowledge and ethics into each other. Consequentially, due to the inescapability of matters of existence and ethics when it comes to studying the past, historical writing cannot be other than essentially contested historical knowledge about the past.

I believe that this perfectly accounts for the question of why all we have are contested histories in the sense of historical writing and why the case is necessarily so. That the past cannot be anything but the terrain of contested knowledge can best be explained by a counterfactual argument highlighting the circumstances under which the past could be uncontested knowledge. The past could be the plane of pure, uncontested and fully dissociated knowledge only if the future 'we' would 'become' - that is, if history as the course of events would eventually end in the ontological becoming of an all-encompassing subject, if the vision of substantive philosophies of history of the Enlightenment and German Idealism came true, if the ultimate fulfilment of the historical process had already happened. Though it usually goes unnoticed, the practical success of those philosophies of history would have petrified the past and hence would have erased the practice of historical writing. For if an ontological subject - humankind, reason, or freedom - would achieve its ultimate truth as history, then historical writing could not be responsible for anything else than for the backward extension of that truth unfolding in history: for writing the ultimate, one and only story of the achievement. 
Ironically enough, this backward extension was the founding principle of historical writing in the shape of a search for the ultimate meaning of the past, even though the actual practice of historical writing never lived up to this principle. In light of all this, it can be said that, since its institutionalization, historical writing has had to face one single ominous threat that came in two interrelated forms. The threat of turning itself into uncontested knowledge approached historical writing either as a potential coming true of the future ultimate meaning of substantive philosophy of history, or as potential self-annihilation through living up to its own founding principle and establishing an ultimate meaning of the past. That such a thing cannot reasonably happen is, I think, wonderfully exhibited in the inescapable feature of the prospective side of history as a disrupted singular. As long as there is no 'becoming' prospectively, as long as there is no ultimate fulfilment of a historical process, historical writing is on the safe side as essentially contested knowledge of the past (that is, of the inseparable blending of the present past and our apophatic past).

\section{We are history}

Arriving at this point, and in place of a conclusion, I cannot escape attempting a more or less clear answer to the initial question about how history qua history inevitably shapes public life. Yet the previous section about the function of historical writing entailed by a quasi-substantive philosophy of history was already, in fact, an implied answer to that question. Thus the best I can do here is to summarize the implied answer: historical writing as essentially contested historical knowledge where contestation is due to the inseparability of matters of knowledge and matters of ethics - 'contributes' to identity formation by revealing what a coming 'we' cannot be, thereby negatively indicating the contours of that very coming 'we' that must remain unknown. In other words, the inevitable public relevance of history as historical writing lies in its constitutive engagement in history as the course of events. Moreover, if history as the course of events is a concept we deploy to make sense of the project of working out senses of togetherness (in terms of 'coming' communities), it can reasonably be viewed as a public endeavour per se - and this is what history as historical writing is ultimately engaged in.

Given all this, the question that demands an answer is not whether this 'contribution' shapes public life, but whether it is best described in terms of a 'contribution.' The point I would like to make is that in a quasi-substantive 
philosophy of history the question of a contribution may not even be asked. The reason for this is what I hope to condense in a formula that already features in the title: 'We are history.' Although, I have to concede, the phrase 'we are history' might mean many things, I certainly do not wish to allude to the British miniseries of the same name, in which the comedian Marcus Brigstocke made fun of historical documentaries, however hilarious its episodes might be for viewers. What I primarily mean by 'we are history' is that historical writing is not so much a contribution to public agendas as the very arena in which public life is at stake. It is the arena itself because of history's dual meaning: because historical writing, its very possibility and the particular shape it takes, is preconditioned by how we conceptualize history as the course of events. Insofar as we have a notion of history regarding the course of events, and insofar as this notion concerns a public endeavour, historical writing cannot but share in the stakes of the endeavour by which it is preconditioned.

There is, however, a logical alternative to this constellation: no concept of history as the course of events, no historical writing. But again, insofar as we are engaged in public endeavours to bring about change in human affairs, we need a concept of history as the course of events that launches that very endeavour, which, in turn, renders historical writing possible. It is not just an accident that the postwar criticism of substantive philosophies of history occurred simultaneously with the most famous essay decrying the public irrelevance of history from White (1966). This simultaneity, I believe, very well supports my ultimate point, namely, that professional historical studies lost touch with the non-academic world less because historical writing failed to keep up with contemporary ways of literary and artistic meaning attribution, as White suggests, and more because history as historical writing lost touch with a concept of history as the course of events. Lacking ties to such a concept is nothing less than lacking ties to our best effort to launch and make sense of the public endeavour of bringing about change in human affairs. What historical writing needs badly to regain its public relevance is to re-connect to a philosophy of history: because insofar as we have a concept of history as the course of events - be it either substantive or quasi-substantive - we are history.

\section{Notes}

1. The above picture, which characterizes the history of historical writing as a series of crises and in which current crisis-talk centres around the public weightlessness of 
the discipline, can, of course, be challenged. Nevertheless, what can hardly be denied is that talking about the public weightlessness of the discipline has been quite a common theme for some time. To be more accurate, it has been quite a common theme since White (1966), regarding which I can offer the following story. Whereas analytical philosophy of history was interested in 'the special conceptual problems which arise out of the practice of history as well as out of substantive philosophy of history' (Danto, 1985,1), and consequently, it remained indifferent to the question of the public relevance of historical writing, the Whitean narrativist approach aimed at the transformation of the discipline precisely on the grounds that it detected a public disinterest in, or even a disdain for, academic history. In order to restore the status of historical studies, White advised historians to keep up with ways of meaning constitution deployed by contemporary art and literary writing. As Whitean narrativism quickly superseded analytical philosophy of history in the 1970s (or at least in the 1980s) and came to dominance, its transformative spirit spread over the discipline while fusing with other lines of thought. At its most extreme, fused with postmodern theories, this transformative spirit took the shape of the suggestion that if historical writing cannot be transformed into something better, then we would do better to forget about it (Jenkins 1999). The transformative intentions, however, survived the demise of postmodern theories. Today, when there is a sense of a necessity to take stock of the theories of the last decades on the one hand (Partner 2009, Spiegel 2009), on the other hand the transformative intentions remain but take a very different shape, as is most tangible in the overwhelming debates around The History Manifesto co-written by Guldi and Armitage (2014). For my intervention see Simon (2015a).

2. Sattelzeit is the period between 1750 and 1850, when - according to Koselleck the transition from early modern to modern took place. Although in discussions of Koselleck it often features as a firm periodization effort, Koselleck $(1996,69)$ rather regarded the concept pragmatically (as a means to manage the enterprise of conceptual history), and also complained about the utility of the concept (suggesting that Schwellenzeit would be a better name).

3. For different but equally classic arguments about the illegitimacy of philosophizing about history as the course of events within the analytic tradition, see Popper (1957) and Danto (1985). For a less known but nonetheless instructive critique from the 
same tradition, see Mandelbaum (1948). For an 'end of history' argument (with an overview and additional arguments about the consequence regarding historical writing as well), within the context of postmodernism, see Jenkins (1999, 26-66). For an argument against the ban, see Runia (2014, 49-53), who also points to a qualification I would like to add. Outside departments of history and philosophy among political scientists and evolutionary biologists (and practically everyone else) philosophizing about the course of events continued to be practiced in the postwar period. The point is that philosophy of history understood as the course of events was deemed to be illegitimate, dangerous, and impossible precisely by those who, in one way or another, otherwise claimed expertise in the disciplines related to the enterprise (philosophy and history).

4. To be clear, I do not wish to conduct an inquiry into the nature of time or the temporality of history. Instead, I look for a specific way of conceiving time that we may call "historical," which might enable us to talk about history as the course of events again without falling prey to substantive thinking. Also, by talking about history as the course of events, I do not wish to talk about the nature of a historical process. What I think (and what has to become clear at the end of this essay) is that conceptualizing history as the course of events is our best effort to initiate, render possible, and make sense of the endeavour of bringing about change in human affairs.

5. In a recent article (Simon 2015a), I dealt more extensively with the unfeasibility of the developmental view on the occasion of discussing White (2014) and Guldi and Armitage (2014). In another article (Simon 2015a) and a talk I gave at The Institute of Historical Research in London under the title 'A Quasi-Substantive Philosophy of History,' I also dealt more extensively with the movement of history and with the features of a quasi-substantive philosophy of history. Here, I do not wish to recite everything I said on those occasions, and even though in this and the next section for the sake of better understanding - I have to touch upon issues I dealt with in the aforementioned articles and talk, my main objective is to elaborate the issue further by drawing the consequences of it for history as historical writing.

6. Nancy's efforts to think the 'coming' or 'taking place' of a community without appealing to substantive ideas may have a resemblance to the Derridean messianic project and Derrida's notion of a 'future-to-come.' What nevertheless clearly 
separates them is that the 'emancipatory promise' Derrida (1994) wishes to retain, even if its most contradictory form, cannot be made sense of without getting rid of the developmental structure that houses it. Emancipation is developmental empowerment and it is actually the paradigmatic political action of the industrial era, perfectly suited to the developmental view of history. Giving a messianic edge to the emancipatory project is less a useful tool and more an obstacle to think a notion of history different from the one we inherited from the Enlightenment and German Idealism, which is what I am after in this essay.

7. They can be put to work despite the rather huge differences of the theories in which these ideas are embedded. To mention a few, Nancy's coming 'we' has nothing to do with Ankersmit's focus on Western civilization as a definite subject of change; Ankersmit's trauma is the loss of an old world, while Runia's trauma is rather connected to the events that lead to such loss. Whereas Runia's 'presence' is the past taking over the present, Nancy's 'presence' concerns not the past but the future, the presently non-presence of existence. Furthermore, Nancy does not attribute a mechanism to history in any sense, Ankersmit does not do so deliberately and Runia often exceeds the framework to which I have restricted him. Runia even gives in to substantive thinking eventually by means of a cultural evolutionary vocabulary (Runia 2014, 179-202), overshadowing his focus on discontinuities with postulating a deeper, all-encompassing continuity. But the point I want to make has not so much to do with the rational reconstruction of their ideas; my point is only that by putting these thinkers to work in a certain way permits conceiving of the movement of history as a quasi-substantive philosophy.

8. I do not wish to claim here that we have new anthropological constants whose internal relations structure historical time in general. I use these expressions in a restricted sense, only to explain the temporality of the notion of history as a disrupted singular.

9. As Harlan (2009) argues, a couple of decades later Oakeshott underwent a reevaluation of his own, growing more sympathetic towards the practical past. 
10. If White's turn to the notion of the practical past were a movie, its Wikipedia page would discuss it in terms of earning 'mixed to average' reviews. For a positive one, see Domanska (2014), for a less positive one, see Lorenz (2014).

11. On experientiality, the classic is Fludernik (1996), who defines narrativity as mediated human experientiality. For her updated view on the question of whether historical accounts can qualify as narratives in terms of experientiality, see Fludernik (2010).

\section{References}

Ankersmit, Frank. 2005. Sublime Historical Experience. Stanford: Stanford University Press.

Badiou, Alain. 2012. The Rebirth of History. Translated by Gregory Elliott. London: Verso.

Bevernage, Berber, and Chris Lorenz. 2012. "Breaking up Time: Negotiating the Borders between Present, Past and Future.” Storia della Storiografia 61: 31-50.

Danto, Arthur C. 1985. Narration and Knowledge: Including the Integral Text of Analytical Philosophy of History. New York: Columbia University Press.

Derrida, Jacques. 1994. Specters of Marx: The State of the Debt, the Work of Mourning and the New International. London: Routledge.

Domanska, Ewa. 2014. "Hayden White and Liberation Historiography." Rethinking History, 19 (4): 640-650.

Ermarth, Elizabeth Deeds. 2011. History in the Discursive Condition: Reconsidering the Tools of Thought. London: Routledge.

Fludernik, Monika. 1996. Towards a „Natural” Narratology. London: Routledge. 
Fludernik, Monika. 2010. "Experience, Experientiality, and Historical Narrative: A View from Narratology." In Erfahrung und Geschichte: Historische Sinnbildung im Pränarrativen, edited by Breyer, Thiemo and Creutz Daniel, 40-72. Berlin: De Gruyter.

Ghosh, Ranjan and Ethan Kleinberg, eds. 2013. Presence: Philosophy, History, and Cultural Theory for the Twenty-First Century. Ithaca: Cornell University Press.

Guldi, Jo and David Armitage. 2014. The History Manifesto. Cambridge: Cambridge University Press.

Gumbrecht, Hans Ulrich. 2004. The Production of Presence: What Meaning Cannot Convey. Stanford: Stanford University Press.

Harlan, David. 2009. “"The Burden of History’ Forty Years Later.” In Re-Figuring Hayden White, edited by Ankersmit, Frank, Ewa Domanska and Hans Kellner, 169189. Stanford: Stanford University Press.

Jenkins, Keith. 1999. Why History? Ethics and Postmodernity. London: Routledge.

Koselleck, Reinhart. 1996. "A Response to the Comments on the Geschichtliche Grundbegriffe." In The Meaning of Historical Terms and Concepts: New Studies on Begriffsgeschichte, edited by Lehmann, Hartmut and Melvin Richter, 59-70. Washington, D. C.: German Historical Insitute.

Koselleck, Reinhart. 2004. Futures Past: On the Semantics of Historical Time. New York: Columbia University Press.

Lorenz, Chris. 2014. "It Takes Three to Tango. History between the 'Practical' and the 'Historical' Past.' Storia della Storiografia 65: 29-46.

Mandelbaum, Maurice. 1948. "A Critique of Philosophies of History." The Journal of Philosophy 45 (14): 365-378.

Mandelbaum, Maurice. 1971. History, Man \& Reason: A Study in Nineteenth-Century Thought. Baltimore: The Johns Hopkins University Press. 
Nancy, Jean-Luc. 1993. "Finite History." In The Birth to Presence. Translated by Brian Holmes and others. Stanford: Stanford University Press, 143-166.

Nancy, Jean-Luc. 2000. Being Singular Plural. Stanford: Stanford University Press.

Oakeshott, Michael. 1966. Experience and Its Modes. Cambridge: Cambridge University Press.

Partner, Nancy. 2009. "Narrative Persistence: The Post-postmodern Life of Narrative Theory," In Re-Figuring Hayden White, edited by Ankersmit, Frank, Ewa Domanska and Hans Kellner, 81-104. Stanford: Stanford University Press.

Paul, Herman. 2015. "Relations to the Past: A Research Agenda for Historical Theorists." Rethinking History, 19 (3): 450-458.

Popper, Karl. 2002 [1957]. The Poverty of Historicism. New York: Routledge.

Runia, Eelco. 2014. Moved by the Past: Discontinuity and Historical Mutation. New York: Columbia University Press.

Simon, Zoltán Boldizsár. 2015a. "History Manifested: Making Sense of Unprecedented Change." European Review of History, 22 (5): 819-834.

Simon, Zoltán Boldizsár. 2015b. "History Set into Motion Again.” Rethinking History, 19 (4): 651-667.

Spiegel, Gabrielle. 2009. "The Task of the Historian." American Historical Review, 114 (1): $1-15$.

White, Hayden V. 1966. “The Burden of History.” History and Theory, 5 (2): 111-134.

White, Hayden. 2010. The Practical Past. Evanston: Northwestern University Press, 2014. 